\title{
New records of caridean shrimps (Decapoda: Caridea) from shallow water along the northern Yucatan peninsula coasts of México
}

Luis Daniel Santana-Moreno, Sammy De Grave and Nuno Simóes

(LDSM) (NS) Programa de Biodiversidad Marina de Yucatán (BDMY), Unidad Multidisciplinaria de Docencia e Investigación (UMDI-Sisal), UNAM-Facultad de Ciencias. Sisal, Yucatán, México. E-mail: (NS)ns@ciencias.unam.mx

(LDSM) Posgrado en Ciencias del Mar y Limnología, UNAM, México.

(SDG) Oxford University Museum of Natural History, Parks Road, Oxford, OX1 3PW, United Kingdom.

\begin{abstract}
The northern coast of the Mexican state of Yucatán has only been cursorily sampled in the past, with most of this effort concentrated on the largest coral reef in the Gulf of México, Arrecife Alacranes. The present study reports on recent collections (June 2008 - September 2013) of caridean shrimp in Yucatán, including Arrecife Alacranes and other reefs, as well as coastal lagoons and beaches. Additionally, a number of species are reported based on older, unidentified museum material. Six species represent new records for the Gulf of México [Janicea antiguensis (Chace, 1972), Gnathophyllum modestum Hay, 1917, Lysmata jundalini Rhyne, Calado and dos Santos, 2012, Periclimenes sandyi De Grave, 2009, Rapipontonia platalea (Holthuis, 1951a), Typton tortugae, McClendon, 1911], and 11 species are confirmed new records for México [Lysmata ankeri Rhyne and Lin, 2006, L. pederseni Rhyne and Lin, 2006, L. rafa Rhyne and Anker, 2007, Ascidonia miserabilis (Holthuis, 1951b), A. quasipusilla (Chace, 1972), Neopontonides chacei Heard, 1986, Periclimenaeus maxillulidens (Schmitt, 1936), P. pearsei (Schmitt, 1932), P. schmitti Holthuis, 1951b, Typton prionurus Holthuis, 1951b, Processa manningi De Grave and Felder, 2012], adding up to a total of 17 newly reported species for the East coast of México. Further, the colour pattern of several species is documented for the first time.
\end{abstract}

Key words: Barbouriidae, biodiversity, Hippolytidae, Palaemonidae, Processidae

\section{INTRODUCTION}

The known fauna of caridean shrimps from the Gulf of México currently comprises 252 species belonging to 73 genera and 22 families (Anker, 2010, 2012; Anker and De Grave, 2010; Felder et al., 2009). Of these, only 103 shallow water species have been reported so far from the eastern coasts of México (Álvarez et al., 1999; Barba et al., 2005; Barba et al., 2010; Escobar-Briones and Jiménez-Guadarrama, 2010; Escobar-Briones and Villalobos-Hiriart, 2003; Felder et al., 2009; García-Madrigal et al., 2002; Goy, 2005; Gracia and HernándezAguilera, 2005; Hermoso-Salazar and ArvizuCoyotzi, 2007; Hernández-Aguilera et al., 2010; Hernández-Aguilera et al., 1996; Hernández et al., 2010; Markham et al., 1990; Martínez-Guzmán and Hernández-Aguilera, 1993; Martínez-Mayén and Román-Contreras, 2006; McClure, 2005; Mejía-Ortiz, 2008; Raz-Guzmán, 2010; Rodríguez-Almaraz et al., 2000; Román-Contreras, 1988; RománContreras and Martínez-Mayén, 2007, 2009, 2010a,b,c; Román-Contreras and RomeroRodríguez, 2005; Soto, 1980; Wicksten, 
2005b; Wicksten, 2005c). Although the knowledge of caridean species in the Mexican part of the Gulf of México is quite considerable, it does not appear exhaustive compared to the effort in the United States region of the Gulf, as the herein included additional records demonstrate.

In order to contribute to the knowledge of carideans along the Mexican coastline of the Gulf of México, a number of sampling campaigns have been carried out since 2008 along the Yucatán peninsula by the BioDiversidad Marina de Yucatán team (BDMY) at Unidad Multidisciplinaria de Docencia e Investigación de Sisal (UMDI-Sisal), concentrating on the largest offshore reef system of the Gulf of Mexico (Arrecife Alacranes) and two of the Sisal banks reef system (Zarco-Perelló et al., 2013) (Serpientes and Madagascar reefs), northeast off the Yucatán peninsula, but supplemented by fieldwork in the marshes, estuaries, and coastal wetlands of north-western Yucatán peninsula, from Celestún to Ría Lagartos (Fig. 1). Some points along the Caribbean coast of México were also sampled (Fig.1).

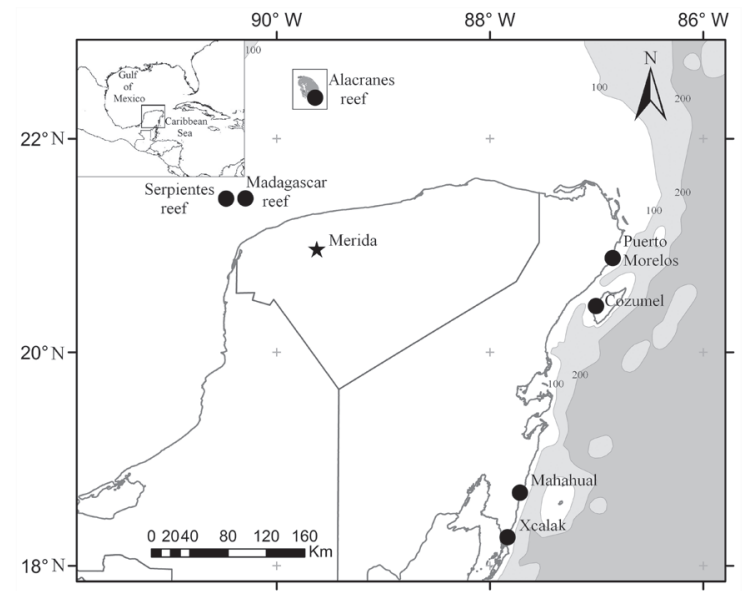

Figure 1. Location of the collecting sites at Yucatan peninsula, México.

\section{Material And Methods}

Sampling was conducted in a focused manner, targeting potentially shrimp rich habitats, such as coral reefs, seagrass beds, tidal flats, coral rubble, and focusing on known host species such as sponges and echinoderms. In general manual collecting was carried out, both by SCUBA and snorkelling as well as by push- net over suitable habitat. Sampling effort was concentrated in the Yucatán Peninsula region (Fig. 1). The studied material is deposited in the Colección de Crustáceos, UMDISisal (YUC-CC); the Colección Nacional de Crustáceos, UNAM, Ciudad de México (CNCR) and in the Zoological Collection of the Oxford University Museum of Natural History, Oxford, United Kingdom (OUMNHZC). Abbreviations used are "pocl" for postorbital carapace length, in $\mathrm{mm}$, and "fen" for field collection number (prefix DSM for the first author, NS for third author). Species reported without fon numbers are based on reidentifications of material by the first author in the CNCR collection. Species were considered to be new records for the Gulf of México, if within the geographical boundaries outlined for the Gulf by Felder et al. (2009) and not previously reported. The classification adopted here follows De Grave and Fransen (2011).

\section{RESUlTS}

\section{Systematics}

Family Barbouriidae Christoffersen, 1987

Janicea antiguensis (Chace, 1972)

(Fig. 2A)

Material examined: 1 female (pocl 7.6), Arrecife Alacranes, 10 Aug. 2009, $22^{\circ} 23^{\prime} 8.88^{\prime \prime} \mathrm{N} 89^{\circ} 42^{\prime} 1.65^{\prime \prime} \mathrm{W}$, on reef wall, below $17 \mathrm{~m}$ depth, nocturnal dive, fon NS178 (OUMNH.ZC.2012.11.001); 1 male (pocl 5.6), Arrecife Alacranes, 10 Aug. 2009, $22^{\circ} 23$ '28.89”N 8942'13.79”W, nocturnal dive, on reef wall, at $19 \mathrm{~m}$ depth, fcn NS-215 (OUMNH.ZC.2012.11.002).

Remarks: The material presents no special features, and corresponds closely with the descriptions of Chace (1972), Manning and Hart (1984) and d'Udekem d'Acoz (2000). The colour pattern of the present specimens (Fig. 2A) matches the material reported from Brazil (Giraldes et al., 2012).

Distribution: Janicea antiguensis has been reported previously from Bermuda, the Bahamas, and Antigua (Kensley, 1988), as well as Fernando de Noronha (Ramos-Porto 


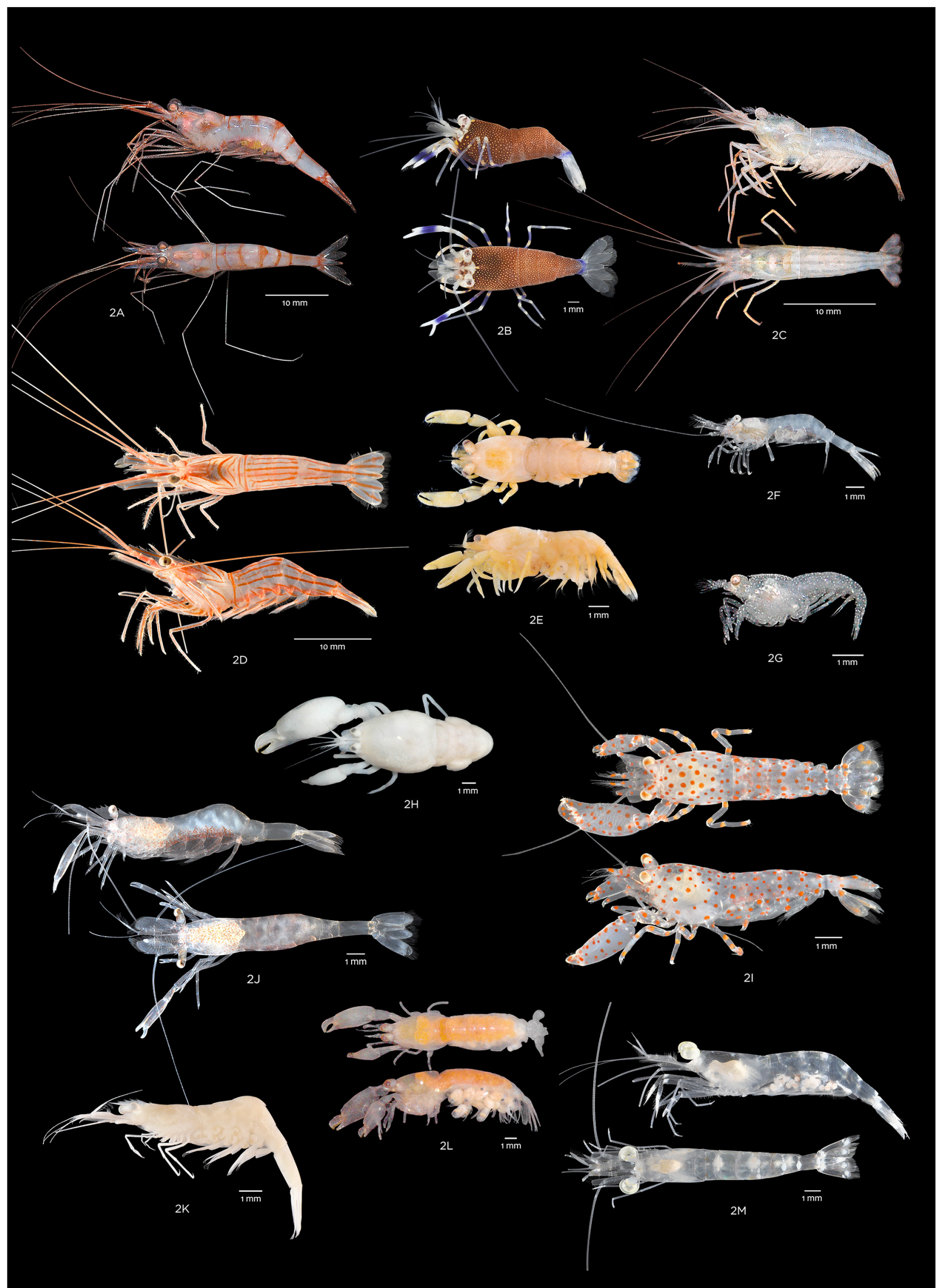

Figure 2: Colour pattern in life of caridean shrimp from the Yucatan Peninsula, Mexico. Specimens (E), $(\mathrm{H})$ and $(\mathrm{K})$ were already dead when photographed and are presented for documentation only. (A) - Janicea antiguensis; (B) - Gnathophyllum modestum; (C) - Lysmata jundalini; (D) - Lysmata pederseni; (E) - Ascidonia quasipusila; (F) - Neopontonides chacei; (G) - Periclimenaeus maxillulidens; (H) - Periclimenaeus pearsei; (I) - Periclimenaeus schmitti; (J) - Periclimenes sandyi; (K) - Rapipontonia platalea; (L) - Typton prionurus; (M) - Procesa manningi 
and Coelho, 1991), Pernambuco and Espírito Santo, Brazil (Giraldes et al., 2012), in the western Atlantic. It is also known from the Cape Verde Islands, São Tomé and the Canary Islands in the eastern Atlantic (d'Udekem d'Acoz, 2000; Wirtz, 2004). Within Mexican waters, the species has been reported from a single anchialine cave system, Cueva Quebrada in Cozumel (Kensley, 1988). Some of Kensley's (1988) material was re-examined by d'Udekem d'Acoz (2000) who erroneously placed this locality inside the Gulf of México. The species has also been recorded from 350 $m$ deep on the Banco Chinchorro escarpment in Quintana Roo (Escobar-Briones and Villalobos-Hiriart, 2003). Although Giraldes et al. (2012) state that the species also occurs in Yucatán, no earlier records substantiating this could be traced. Thus, the present specimens constitute the first confirmed record of the species for the Gulf of México coast of México and by extension the entire Gulf.

Family Gnathophyllidae Dana, 1852 Gnathophyllum modestum Hay, 1917

(Fig. 2B)

Material examined: 1 male (pocl 2.7), North Madagascar Reef, Yucatan, 4 Sept. 2013, 21 ${ }^{\circ} 28^{\prime} 37.38^{\prime \prime N} 90^{\circ} 17^{\prime} 14.76^{\prime \prime W}, 24 \mathrm{~m}$ depth, hand collected under calcareous slate rock in sand bottom, fen DSM-225te (YUCCC-255-11-000365); one unsexed specimen observed and photographed in Veracruz, Veracruz, 27 Mar. 2012, 19¹1'34.85”N $96^{\circ} 7^{\prime} 24.05^{\prime \prime} \mathrm{W}, 2 \mathrm{~m}$ depth, hand collected at the fisherman pier in sand-rock bottom by José Francisco Rendón Hernández; observation of one male and an ovigerous female, North Madagascar Reef, Yucatan, 3 Sept. 2013, $21^{\circ} 27^{\prime} 16.74$ ” $90^{\circ} 19^{\prime} 03.96$ 'W, $24 \mathrm{~m}$ depth, under a calcareous slate rock on sand bottom.

Remarks: The present specimen only has five dorsal teeth and one minute distal ventral tooth, corresponding to Manning's (1963) description. According to Manning (1963), the color pattern of living material is a diagnostic feature in this genus and the present specimen matches the colour notes in Manning (1963) (Fig. 2B) with a deep brown background carapace and abdomen, many scattered small yellow spots throughout the somites and a few larger orange spots towards the frontal part of the body. This specimen has an anterior series of 2 antero-dorso-lateral orange spots on each side of the carapace and a series of 3 larger orange spots ventrally, on the base of each first maxilliped.

Distribution: Although this species is considered to have a wide distribution in the western Atlantic, there are in reality few published records of it (Dardeau et al., 1980; Hay, 1917; Hay and Shore, 1918; Manning, 1963). Within Mexican waters, this is the first record of the species in Veracruz and north Madagascar Reef in Yucatan.

Family Hippolytidae Spence Bate, 1888 Lysmata ankeri Rhyne and Lin, 2006

Material examined: 2 ovigerous hermaphrodites (pocl 6.4, 7.0), 1 nonovigerous hermaphrodite (pocl 4.2), Quintana Roo, Playa María Irene, aprox. $4 \mathrm{~km}$ al $\mathrm{N}$ de la Estación de Ciencias de Mar y Limnología, UNAM, Puerto Morelos, Municipio de Benito Juárez, 27 Jun. 1988, leg. J.L. Villalobos, J.C. Nates, A. Cantú, P. Schmidsdorf and P. Flores [CNCR4925, original identification L. wurdemanni (Gibbes, 1850)]; 2 ovigerous hermaphrodites (pocl 8.4, 10.6), Punta Estrella (2049'56.12”N 86 53'22.15”W), Puerto Morelos, Municipio de Benito Juárez, Quintana Roo, 27 Jun. 1988, leg. J.L. Villalobos, J.C. Nates, A. Cantú, P. Schmidsdorf and P. Flores [CNCR9871, original identification L. moorei (Rathbun, 1901)]; 3 non-ovigerous hermaphrodites (pocl 5.3, 5.9, 6.5), Punta Estrella $\left(20^{\circ} 49^{\prime} 56.12^{\prime} \mathrm{N}\right.$ $86^{\circ} 53$ '22.15”W), Puerto Morelos, Municipio de Benito Juárez, Quintana Roo, 27 Jun. 1988, leg. J.L. Villalobos, J.C. Nates, A. Cantú, P. Schmidsdorf and P. Flores [CNCR9865, original identification L. moorei (Rathbun, 1901)]; 4 non-ovigerous hermaphrodites (pocl 2.9, 3.9, 6.4, 8.8), Playa María Irene, aprox. $4 \mathrm{~km}$ al $\mathrm{N}$ de la Estación de Ciencias de Mar y Limnología, UNAM, Puerto Morelos, Municipio de Benito Juárez, Quintana Roo, 27 Jun. 1988, leg. J.L. Villalobos, J.C. 
Nates, A. Cantú, P. Schmidsdorf and P. Flores [CNCR9734, original identification L. moorei (Rathbun, 1901)].

Remarks: This material close corresponds to the type description (Rhyne and Lin, 2006), with the more than 34 carpal segments of the second pereiopod and the rostrum not over-reaching the antennular peduncle being characteristic for the species.

Distribution: The species appears to be widespread, ranging from Florida southwards to Brazil (Rhyne and Lin, 2006; Wirtz et al., 2009). Although the species was known to occur in the northern Gulf of México (Rhyne and Lin, 2006), it had not been previously recorded in Mexican waters.

\section{Lysmata jundalini Rhyne, Calado and dos Santos, 2012}

(Fig. 2C)

Material examined: 2 ovigerous hermaphrodites (pocl 4.6,6.0), 1 non-ovigerous hermaphrodite (pocl 3.5), Arrecife Alacranes, 09 Aug. 2009, 22²3'5.57”N 89³8'22.70”W, $2 \mathrm{~m}$ depth, on large dead Montipora sp., fon NS-159 (YUC-CC-255-11-428); 2 ovigerous hermaphrodites (pocl 4.7, 4.8), Arrecife Alacranes, 09 Aug. 2009, 22 23'5.57'N 89.38'22.70"W, $2 \mathrm{~m}$ depth inside dead conch, Strombus gigas (Linnaeus, 1758), fcn NS-171 (OUMNH.ZC.2012.11.003); 8 ovigerous hermaphrodites (pocl 4.8-5.8), 8 non-ovigerous hermaphrodites (pocl 2.35.5), Arrecife Alacranes, 09 Aug. 2009, $22^{\circ} 23^{\prime} 5.57^{\prime \prime} \mathrm{N} 89^{\circ} 38^{\prime} 22.70^{\prime \prime} \mathrm{W}, 2 \mathrm{~m}$ depth, on large dead Montipora sp., fon NS-186 (OUMNH.ZC.2012.11.004).

Remarks: The majority of the material corresponds close to the type description (Rhyne et al., 2012) in having 22-24 fused segment on the lateral antennular flagellum, as well as three accessory spines on the dactyl of the ambulatory pereiopods. However, two ovigerous females harboured four accessory spines on the dactyl on all ambulatory pereiopods, but with 22 and 24 fused antennular segments respectively. The colour pattern of the present material clearly shows the blue spot on the coxa of the fourth pereiopod, considered characteristic for the species (Rhyne et al., 2012).

Distribution: The species was previously only known from Cayo Enrique, La Parguera, Puerto Rico (Rhyne et al., 2012), but is known to be more widespread in the southern Caribbean (De Grave and Anker, pers. obs.). The present specimens extends its distribution considerably north-westwards to Arrecife Alacranes and constitute the first record for the Gulf of México, as well as México.

Lysmata pederseni Rhyne and Lin, 2006 (Fig. 2D)

Material examined: 1 non-ovigerous hermaphrodite (pocl 9.2), Arrecife Alacranes, 13 Jun. 2008, 22³4'36.12”N $89^{\circ} 42^{\prime} 42.60^{\prime \prime} \mathrm{W}$, fcn ALA-073 (YUCCC-255-11-366); 2 ovigerous hermaphrodite (pocl 10.2, 10.4), Arrecife Alacranes, 13 Jun. 2008, 22³4'36.12”N 8942'42.60”W, fcn. ALA-076 (YUC-CC-255-11-367); 1 non-ovigerous hermaphrodite (pocl 6.6), 1 ovigerous hermaphrodite (pocl 8.1), Arrecife Alacranes, 13 Aug. 2009, 22²7'9.72”N $89^{\circ} 45^{\prime} 44.90$ "W, fon NS-210 (YUCCC-255-11-455); 1 ovigerous hermaphrodite (pocl 7.8), Arrecife Alacranes, 07 Aug. 2009, $22^{\circ} 33^{\prime} 17.28^{\prime \prime} \mathrm{N} 89^{\circ} 47^{\prime} 18.60^{\prime \prime} \mathrm{W}$, fcn NS-145 (YUC-CC-255-11-421); 1 non-ovigerous hermaphrodite (pocl 6.5), Arrecife Alacranes, 08 Aug. 2009, 22³0'42.84”N 8947'53.40”W, fcn NS-151 (YUC-CC-255-11-425); 1 ovigerous hermaphrodite (pocl 12.6), Arrecife Alacranes, 08 Aug. 2009, 22³0'42.84” N $89^{\circ} 47^{\prime} 53.40$ ”W, fcn NS-161 (OUMNH. ZC.2012.11.005); 1 non-ovigerous hermaphrodite (pocl 7.1), Arrecife Alacranes, 10 Aug. 2009, 22²3'8.88”N 8942'1.70”W, night diving, $14 \mathrm{~m}$ depth, fon NS-179 (YUC-CC-255-11-442); 1 non-ovigerous hermaphrodite (pocl 6.7), Arrecife Alacranes,

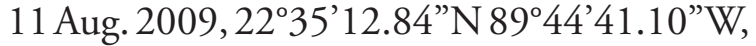
fon NS-190 (YUC-CC-255-11-449); 1 non-ovigerous hermaphrodite (pocl 7.5), 1 ovigerous hermaphrodite (pocl 8.9), Arrecife Alacranes, 27 Febr. 2011, 22³1'6.60”N $89^{\circ} 46^{\prime} 6.70$ "W, $12 \mathrm{~m}$ depth, fon DSM033 (YUC-CC-255-11-160); 2 ovigerous 
hermaphrodite (pocl 9.5, 12.5), 1 nonovigerous hermaphrodite (pocl 7.8), Arrecife Alacranes, 19 Febr. 2012, 22²3'12.89"N 89.40'44.72”W, $9 \mathrm{~m}$ depth, fon DSM-177 (YUC-CC-255-11-319); 1 non-ovigerous hermaphrodite (pocl 9), Arrecife Alacranes, 24 Feb. 2011,22³1'11.60”N 8945’34.20”W,2 m depth, fcn DSM-185 (YUC-CC-255-11-327); 1 non-ovigerous hermaphrodite (pocl 3.2), Arrecife Alacranes, 24 Feb. 2011, $22^{\circ} 31^{\prime} 11.60^{\prime \prime} \mathrm{N} 89^{\circ} 45^{\prime} 34.20^{\prime \prime W}, 5 \mathrm{~m}$ depth, fcn DSM-190 (YUC-CC-255-11-332); 1 nonovigerous hermaphrodite (pocl 3.8), Arrecife Madagascar, 12 Aug. 2008, 21 $26^{\circ} 17.33^{\prime \prime N}$ $90^{\circ} 16^{\prime} 39.27^{\prime \prime} \mathrm{W}, 14 \mathrm{~m}$ depth, fcn DS-13 (YUC-CC-255-11-385); 2 non-ovigerous hermaphrodites (pocl 5.7, 10.9), Arrecife Madagascar, 10 Jun. 2011, 21 $26^{\circ} 28.30^{\prime \prime N}$ $90^{\circ} 17^{\prime} 34.01^{\prime \prime} \mathrm{W}, 8 \mathrm{~m}$ depth, fon DSM108 (YUC-CC-255-11-237); 1 ovigerous hermaphrodite (pocl 6.4), Quintana Roo, no further details, 21 Aug. 1990, leg. L. Soto, E. Escobar and J.L. Villalobos [CNCR10788, original identification L. rathbunae (Chace, 1970)].

Remarks: The material corresponds closely to the type description (Rhyne and Lin, 2006) and presents no special features. All material collected during the present study from Arrecifes Madagascar and Alacranes was collected from inside the osculum or on the outside of Callyspongia vaginalis (Lamarck, 1814), which is one of the main host species (Rhyne and Lin, 2006). The colour pattern of the present material closely matches the type material (Rhyne and Lin, 2006).

Distribution: The species ranges from Florida southwards to Venezuela (Rhyne and Lin, 2006). Although widespread including the northern Gulf of México, the present specimens constitute the first record of the species from Mexican waters.

\section{Lysmata rafa Rhyne and Anker, 2007}

Material examined: 1 non-ovigerous hermaphrodite (pocl 4.6), Arrecife Alacranes, 04 Aug. 2009, 22²3'7.85”N 8940'2.48”W, fcn NS-122 (YUC-CC-255-11-411).
Remarks: The single specimen is typical for the species with a long, upwardly curved rostrum with seven dorsal and eight ventral teeth, elongated third maxillipeds as well as elongated ambulatory pereiopods (Rhyne and Anker, 2007).

Distribution: The species was previously only known from Biscayne Bay and Key West Lakes, Florida (Rhyne and Anker, 2007). The present specimen extends its distribution considerably southwards and constitutes the first record for México.

Family Palaemonidae Rafinesque, 1815

Ascidonia miserabilis (Holthuis, 1951b)

Material examined: 1 male (pocl 1.55), Isla Cozumel, $1 \mathrm{~km}$ south of Playa Corona, shallow near-shore rubble flat with seagrass, algae, and fan corals, abundant algae-overgrown rubble, depth $0.5-1 \mathrm{~m}$, in Ascidia sp. attached under rocks [host preserved], 9 Jul. 2010, collected by A. Anker, J Duarte-Gutierrez. fcn COZ3-014 (OUMNH.ZC.2013.05.017).

Remarks: The single specimen corresponds closely to the redescription of the species by Fransen (2002), as well as the additional material reported in Pachelle et al. (2012). The white dotted colour pattern, however, differs from the Honduras, Panama and Brazil specimens therein, which have marked yellow dots.

Distribution: The species is widespread, ranging from the northern part of the Gulf of México (Wicksten, 2005a), Caribbean (Fransen, 2002, 2006; Holthuis, 1951b), to Atol das Rocas (Brazil) (Pachelle et al., 2012). Although recorded in the northern part of the Gulf of México, the present specimen represents the first record of the genus in Mexican waters.

Ascidonia quasipusilla (Chace, 1972)

(Fig. 2E)

Material examined: 1 ovigerous female (pocl 2.2), Arrecife Alacranes, 18 Feb. 2012, $22^{\circ} 23^{\prime} 12.89^{\prime \prime} \mathrm{N} \quad 89^{\circ} 40^{\prime} 44.72^{\prime \prime} \mathrm{W}, \quad$ inside unidentified ascidian, $7 \mathrm{~m}$ depth, fcn DSM164 (OUMNH.ZC.2012.11.006). 
Remarks: The present specimen corresponds closely to the re-description of the species (Fransen, 2002), although it is the smallest ovigerous female known to date. The specimen has 15 large eggs $(0.4-0.5 \mathrm{~mm})$ (Fig. 2E), contrasting to the Mauritanian material examined by Fransen (2002) which had 100200 eggs $(0.6-0.7 \mathrm{~mm})$. The number of eggs of the female holotype from Antigua (Chace, 1972) is not known, which is the only other known ovigerous specimen from the West Atlantic. This difference between West and East Atlantic specimens assigned to this species warrants closer scrutiny.

Distribution: The species was previously recorded from Antigua and Martinique (Chace, 1972) as well as Guadeloupe (Fransen, 2002) in the western Atlantic, and Mauritania in the eastern Atlantic (Fransen, 2002). The present specimen constitutes the first record of the species for the Gulf of México, and thus by extension México.

Neopontonides chacei Heard, 1986

(Fig. 2F)

Material examined: 1 ovigerous female (pocl 1.1), 6 males (pocl 0.6-1.0), Arrecife Alacranes, 11 Aug. 2009, 22³5'12.70”N $89^{\circ} 44^{\prime} 41.10$ "W, $27 \mathrm{~m}$ depth, on the octocoral Pseudopterogorgia americana (Gmelin, 1791), fon NS-197-1 (OUMNH.ZC.2012.11-007); 1 male (pocl 1.7), Arrecife Madagascar, 07 Jun. 2011, 21 26 $26^{\prime} 17^{\prime \prime} \mathrm{N} 90^{\circ} 16^{\prime} 38.2^{\prime \prime} \mathrm{W}, 7$ m depth, on P. americana, fcn DSM-066-1 (YUC-CC-255-11-194); 1 ovigerous female (pocl 1.2), Punta Norte, Isla Pérez, Arrecife Alacranes, 20 Feb. 2011, 22 23'08.90”N, $89^{\circ} 40^{\prime} 53.40^{\prime \prime} \mathrm{W}, 4 \mathrm{~m}$ depth, on $P$. americana, fcn DSM-004.

Remarks: The present specimens correspond closely to the type description (Heard, 1986) in harbouring equal and similar second pereiopods, slender ambulatory pereiopods with a poorly developed or absent tubercle on the distal flexor margin of the merus. The colour pattern (Fig. 2F) shows the species to be largely transparent, with some scattered red dots on the carapace and the lateral sides of the pleura.
Distribution: Previously reported from Marigot Bay, St. Lucia Island, Falmouth, Antigua, Carrie Bow Cay, Belize, Looe Key and Bahia Honda Key, Florida (Heard, 1986), Honduras associated with $P$. americana (De Grave, 2009) and the northern Gulf of México associated with Leptogorgia spp. (Wicksten and Cox, 2011). The present records from Arrecifes Alacranes and Madagascar constitute the first record for Mexican waters.

\section{Periclimenaeus maxillulidens (Schmitt, 1936)}

(Fig. 2G)

Material examined: 2 females (pocl 1.4, 1.4), Arrecife Alacranes, 05 Aug. 2009, $22^{\circ} 23^{\prime} 17.90^{\prime \prime} \mathrm{N} 89^{\circ} 42^{\prime} 8.78^{\prime \prime} \mathrm{W}$, inside dead conch on sandy flats, fcn NS-158 (OUMNH. ZC.2012.11.008).

Remarks: The material is damaged, with one specimen missing the telson, both second pereiopods as well as the left third and fourth pereiopod, whilst the other specimen lacks the major second pereiopod as well as both fifth pereiopods. The rostrum in both specimens is short, barely reaching the distal margin of the eye, harbouring one and two dorsal teeth, respectively. The short, poorly armed rostrum, combined with a simple dactylus on the ambulatory pereiopods as well as a short distolateral tooth on the scaphocerite and the lack of the anterolateral tooth on the basal segment of the antennular peduncle, confidently secures the identity of these specimens. The colour pattern (Fig. 2G) shows the species to be largely transparent, but with a dense covering of small, white dots all over the body, pereiopods, uropods, telson and uropods.

Distribution: The species was previously only known from a single specimen from Bonaire, with the habitat described as sandy debris behind the reef (Schmitt, 1936) and a further non-ovigerous female from off Cape San Blas, Florida, collected on coarse grey sand, broken shells, gravel, sand, coral (Holthuis, 1951b). As the present specimens were collected inside a dead conch shell, it remains unknown whether the species associates with sponges or ascidians. The present specimens constitute the first record of the species for México. 
Periclimenaeus pearsei (Schmitt, 1932) (Fig. 2H)

Material examined: 1 ovigerous female (pocl 5.5), 1 male (pocl 4.3), Arrecife Serpientes 15 Jun. 2011, 2126'22.3”N 90²8'25.4”W, $11 \mathrm{~m}$ depth, inside sponge Ircinia strobilina (Lamarck, 1816), fcn DSM-123 (OUMNH. ZC.2012.11.009).

Remarks: The specimens corresponds closely to the re-description of the species in Holthuis (1951b), with the globose carapace, the rostral dentition $(4 / 0)$ as well as the shape of the minor second pereiopod being characteristic of the species. The colour pattern of the species is not known (Fig. 2H).

Distribution: The species was previously only known from the Dry Tortugas, Florida (Holthuis, 1951b) from Spongia officinalis Linnaeus 1758 and Maranhão, Brazil (RamosPorto and Coelho, 1990), between 46-52 m depth. The present specimens present the first record of the species for México, a different host record, as well as being much shallower than previously recorded.

\section{Periclimenaeus schmitti Holthuis, 1951b}

(Fig. 2I)

Material examined: 1 ovigerous female (pocl 2.5), 1 male (pocl 2.2), Arrecife Madagascar, 07 Jun. 2011, 2126'17”N $90^{\circ} 16^{\prime} 38.2^{\prime} \mathrm{W}, 12 \mathrm{~m}$ depth, inside sponge Aplysina fistularis (Pallas, 1766), fcn DSM-068 (OUMNH.ZC.2012.11.010); 1 ovigerous female (pocl 2.3) Arrecife Madagascar, 10 Jun. 2011, $21^{\circ} 26^{\prime} 28.3^{\prime \prime} \mathrm{N} 90^{\circ} 17^{\prime} 34.0^{\prime \prime} \mathrm{W}, 8 \mathrm{~m}$ depth inside $A$. fistularis, fen DSM-097 (OUMNH. ZC.2012.11.011); 3 ovigerous females (pocl 2.0, 2.3, 2.5), 4 females (pocl 1.7-2.0), 4 males (pocl 1.3-1.9), Arrecife Alacranes, 24 Feb. 2012,

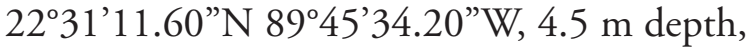
inside Monanchora arbuscula (Duchassaing and Michelotti, 1864), fcn DSM-191 (YUCCC-255-11-333); 1 ovigerous female (pocl 2.6), Arrecife Madagascar, 29 May 2012 $21^{\circ} 26^{\prime} 30.10^{\prime \prime} \mathrm{N} 90^{\circ} 17^{\prime} 25.90^{\prime \prime} \mathrm{W}, 20 \mathrm{~m}$ depth, inside Mycale laxissima (Duchassaing and Michelotti, 1864), fcn DSM-212 (OUMNH. ZC.2012.11.012).
Remarks: The specimens are typical for the species (Holthuis, 1951b) and present no noteworthy features. The lack of a distolateral tooth on the scaphocerite, combined with biunguiculated dactyls on the ambulatory pereiopods characterizes this species. The present record confirms the species to be associated with sponges, occurring in Lissodendoryx colombiensis Zea and van Soest, 1986, Aplysina fistularis (Pallas, 1766), Monanchora arbuscula (Duchassaing De Fonbressin and Michelotti, 1864) and Mycale laxissima (Duchassaing De Fonbressin and Michelotti, 1864). The colour pattern of the present material closely matches that in De Grave and Fransen (2011), based on material from Bocas del Toro (Panama) (Fig. 2I).

Distribution: The species was previously known from Bogue Sound, North Carolina and the Dry Tortugas, Florida (Chace, 1972; Williams, 1965). Garcia-Madrigal et al. (2002) also recorded the species from an unspecified location in Quintana Roo in a regional checklist. The present record is the first for the southern Gulf of México.

Periclimenes sandyi De Grave, 2009 (Fig. 2J)

Material examined: 2 ovigerous females (pocl 2.7, 3.0), 1 male (pocl 2.7), Desterrada Island on Arrecife Alacranes, 27 Feb. 2011, 2231'06.6” N 8946'06.7”W, 12 m depth, fon DSM-034 (OUMNH.ZC.2012.11.013); 2 ovigerous females (pocl 2.3, 2.7), Pérez Island channel on Arrecife Alacranes, 18 Feb. 2012, $22^{\circ} 23^{\prime} 12.89^{\prime} \mathrm{N} 89^{\circ} 40$ '44.72”W, $7 \mathrm{~m}$ depth, fon DSM-165 (OUMNH.ZC.2012.11.014); 8 females (pocl 2.1-2.8), Desterrada Island on Arrecife Alacranes, 24 Feb. 2012, $22^{\circ} 31^{\prime} 11.60$ ” N 8945'34.20”W, 5 m depth, fcn DSM-189 (OUMNH.ZC.2012.11.015); 3 ovigerous females (pocl 2.0, 2.0, 2.2), 1 male (pocl 1.9), Arrecife Alacranes, 07 Aug. 2009, $22^{\circ} 33^{\prime} 17.28^{\prime \prime} \mathrm{N} 89^{\circ} 47^{\prime} 18.60^{\prime \prime W}$, fen NS-146 (OUMNH.ZC.2012.11.016); 1 ovigerous female (pocl 2.6), Arrecife Alacranes, 11 Aug. 
2009, 22 35'12.84”N 8944'41.10”W, fon NS-188 (OUMNH.ZC.2012.11.017); 2 ovigerous females (pocl 2.0, 2.5) 3 males (pocl 1.3, 1.5, 1.8), Arrecife Alacranes, 11 Aug. 2009, 22 $35^{\prime} 12.84 ” \mathrm{~N} 89^{\circ} 44^{\prime} 41.10^{\prime \prime W}, \mathrm{fcn}$ NS-189 (OUMNH.ZC.2012.11.018).

Remarks: The specimens correspond closely to the type description (De Grave, 2009), harbouring asymmetrical second pereiopods, with two teeth on the cutting edges of the major chelae. The present records confirm that the host species is Callyspongia vaginalis, with all specimens collected from the osculum. In general, females are larger than males, eggs in ovigerous females measure 0.4$0.5 \mathrm{~mm}$ diameter. The colour pattern of the species is now illustrated for the first time (Fig. $2 \mathrm{~K}$ ), and the species is largely transparent, but with a dense scattering of red dots on the carapace and the ventral side of the pleura, as well as the second pereiopods.

Distribution: Previously only known from the type locality, Crawl Cay, Bocas del Toro, Panama (De Grave, 2009). The present record constitutes a significant northwardly extension, as well as the first record for the Gulf of México and by extension, Mexican waters.

\section{Rapipontonia platalea (Holthuis, 1951a)}

(Fig. 2K)

Material examined: 1 ovigerous female (pocl 2.3), 1 male (pocl 1.6), Arrecife Madagascar, 12 Aug. 2008, 2126'22.15”N $90^{\circ} 17^{\prime} 9.07^{\prime \prime} \mathrm{W}, 14 \mathrm{~m}$ depth, fcn DS-06 (OUMNH.ZC.2012.11.019).

Remarks: The present specimens correspond closely to the descriptions in Holthuis (1951a) and Marin (2009) in their general features but harbour fewer dorsal rostral teeth (6 in the male and 5 in the female, respectively), corresponding to some of the specimens illustrated by Marin (2009).

Distribution: The species has been recorded from Senegal, Cape Verde, São Tomé and off Guinea in the eastern Atlantic (Holthuis, 1951a; Marin, 2009; Wirtz and d'Udekem d'Acoz, 2001; Wirtz and De Grave, 2010). Within the western Atlantic, the species was previously only known from Tobago (Hale and De Grave, 2007), the present specimens thus represent the first record of the species for México and the Gulf of México. In contrast to the other species in the genus, which only associate with hydroids (Marin, 2009), $R$. platalea has been found on hydroids (Hale and De Grave, 2007), black coral (Wirtz and d'Udekem d'Acoz, 2001) and gorgonians (Wirtz and d'Udekem d'Acoz, 2001; Wirtz and De Grave, 2010), although the host of the current specimens is not known.

Typton prionurus Holthuis, 1951b

(Fig. 2L)

Material examined: 1 ovigerous female (pocl 3.7), Arrecife Serpientes, 13 Jun. 2011, 21²6'22.3”N 90²8'25.4”W, $17 \mathrm{~m}$ depth, from Tedania ignis (Duchassaing and Michelotti, 1864) sponge, fon DSM-116 (OUMNH.ZC.2012.11.020).

Remarks: The specimen corresponds closely to the re-description of the type material in Holthuis (1951b) and presents no noteworthy features. The specimen has a pocl of $3.7 \mathrm{~mm}$, harbouring 15-20 eggs with $0.4-$ $0.6 \mathrm{~mm}$ in diameter. The colour pattern of the species is now illustrated for the first time and shown to be largely transparent, with an orange-red hue (Fig. 2L).

Distribution: The species was previously only known with certainty from the type material from the Dry Tortugas, Florida (Holthuis, 1951b), although a questionable record exists from off Pará, Brazil (Bullis and Thompson, 1965). The present record is the first for México.

\section{Typton tortugae McClendon, 1911}

Material examined: 2 males, Puerto Morelos, Municipio de Benito Juárez, Quintana Roo. Aug. 1984. leg. E. Escobar, from the sponge Ircinia strobilina (Duchassaing De Fonbressin and Michelotti, 1864) (CNCR4693).

Remarks: The specimens correspond closely to the re-description of the species by Holthuis (1951b) and present no noteworthy features. 
Distribution: The species is known from Bermuda, the Dry Tortugas, Virgin Islands, the Brazilian states of Pará and Maranhão as well as Fernando de Noronha (Vieira et al., 2012). Additionally, the species has been recorded in the Gulf of California (East Pacific) by Wicksten (1983). The present specimen represents the first record for the Gulf of México.

Family Processidae Ortmann, 1890

Processa manningi De Grave and Felder, 2012 (Fig. 2M)

Material examined: 1 ovigerous female (pocl 4.0), 1 male (pocl 3.7) Xcalak, Quintana Roo, 19 Apr. 2011, 18¹6’3.11”N $87^{\circ} 50^{\prime} 7.35^{\prime \prime} \mathrm{W}$, on muddy and fine shells bottom burrows, fon DSM-054 (OUMNH. ZC.2012.11.021); 1 male (pocl 4.0), Mahahual, Quintana Roo, 05 Apr. 2012, $18^{\circ} 41^{\prime} 6.69^{\prime \prime} \mathrm{N} 87^{\circ} 43^{\prime} 8.16^{\prime \prime} \mathrm{W}$, on muddy and fine shells bottom burrows, fcn DSM-220 (OUMNH.ZC.2012.11.022).

Remarks: All specimens are damaged with many pereiopods missing, although the ovigerous female has both second pereiopods, which are strongly asymmetrical. The material is assigned to $P$. manningi on account of the unarmed stylocerite, the presence of a small posteromedian tooth on the lobe on the sixth pleonite, the presence of an anteromedial row of setae on the telson and the strongly developed antennal spine. In comparison with the type material (De Grave and Felder, 2012), the longitudinal, lateral row of setae on the telson is poorly developed in two specimens, although this could be due to abrasion during sampling. The colour pattern (Fig. 2M) of the present specimens matches the type material in De Grave and Felder (2012). The specimens were obtained by yabby pump on very shallow, muddy and fine shell bottoms in burrows, likely made by callianassids. Although no callianassids were collected in the same burrows as $P$. manningi, Neocallichirus grandimana (Gibbes, 1850), the host species in Belize (De Grave and Felder, 2012), was common in the same habitat.
Distribution: The species was previously only known from Belize (De Grave and Felder, 2012), the present record extends its distribution into the south Caribbean coast of México.

\section{Discussion}

The present contribution details six new records for the Gulf of México, as well as 11 new records for Mexican waters. This raises the known caridean shrimp fauna of the Gulf of México to 258 species, of which 114 are currently known from shallow, coastal waters in México. As an estimated 35-40 caridean species in the Gulf of México are exclusively known from continental slopes and deeper, it thus appears that the known shallow water Mexican fauna approximates only half the total caridean biodiversity in the Gulf. Certain areas along the Mexican part of the Gulf appear well sampled, for instance Tamaulipas and Campeche, due to local shrimp fisheries and oil industry, however these are primarily sedimentary environments, which hold relatively little caridean biodiversity compared to reefs. The more complex inshore and offshore reef systems and associated environments in Veracruz and Yucatán remain relatively poorly sampled to date, and are likely to hold considerably higher numbers of species, as the current records amply demonstrate.

Despite the perceived lower sampling effort in reefal environments along the southern coastline of the Gulf of México, an examination of available species lists, does show that both Veracruz and Yucatán, already have a rich caridean biodiversity, with 69 and 104 species known, respectively. In contrast, the known species fauna of Campeche is lower at 56 species. Of all the Mexican states along the Gulf of México coast, Tamaulipas and Tabasco appear to hold lower diversity, at 10 and 3 species respectively. As already discussed, this is likely linked to sedimentary environments predominating in those area. Although the small number of species known from Tabasco does suggest a lack of sampling effort.

The total number of species known from Yucatán (104) compares favourably with the 83 
known species from Quintana Roo along the Caribbean coast, which historically has seen more sampling effort. To further document the expected rich biodiversity of these areas, concerted sampling as well as deploying novel collecting techniques, such as yabby pumping, bait and light trapping would be beneficial.

\section{ACKNOWLedgements}

- DSM was supported by CONACyT 245870 grant, field and lab work was supported by CONACyT grants SEMARNAT-108285 and DGAPA-PAPIMEPE207210 (UNAM) projects to NS. All specimens were collected under Mexican law (collecting permit number: 11802.271109.4094). We thank SEMAR and CONANP staff at Alacranes and Xcalak National Parks, for their helpful assistance during field work. Dr. Fernando Álvarez and Dr. José Luis Villalobos (CNCR Instituto de Biologia, UNAM, México) provided access to specimens deposited at their collections. Dr. Arthur Anker collected and provided the Ascidonia miserabilis specimen. Francisco Rendón observed, photographed and collected a specimen of Gnathophyllum modestum that was lost. M.Sc. Gemma Martínez-Moreno helped with photography, whilst M.Sc. Maribel BadilloAlemán and Dr. Patricia Guadarrama-Chávez (UMDISisal) helped with general lab work and microscopy, respectively. B.Sc. Shirley Ucan (UADY), B.Sc. Julio Duarte (UADY) and B.Sc. Diana Ugalde (ICMyL, UNAM) helped during field collecting. M.Sc. Alfredo Gallardo-Torres organized field logistics. Campaign boats were sailed by Fernando Mex (UMDI-Sisal "Kaak-Naab") plus Don Marce, Rafa and Melitón ("El Arlequín”).

\section{REFERENCES}

Álvarez, F.; Villalobos, J.L.; Rojas, Y. and Robles, R. 1999. Listas y comentarios sobre los crustáceos decápodos de Veracruz, México. Anales del Instituto de Biologia, Universidad Nacional Autónoma de México, 70: 1-27.

Anker, A. 2010. A new genus and three new species of alpheid shrimps (Crustacea, Decapoda, Caridea) from the tropical American coasts. Zootaxa, 2652: 47-63.

Anker, A. 2012. Revision of the western Atlantic members of the Alpheus armillatus H. Milne Edwards, 1837 species complex (Decapoda, Alpheidae), with description of seven new species. Zootaxa, 3386: 1-109.

Anker, A. and De Grave, S. 2010. Holthuisaeus, a new genus for Periclimenes (Periclimenaeus) bermudensis Armstrong, 1940 (Decapoda, Palaemonidae, Pontoniinae). In: Fransen, C.H.J.M.; De Grave, S. and Ng, P.K.L. (Eds.), Studies on Malacostraca: Lipke Bijdeley Holthuis memorial volume. Brill, Leiden; Crustaceana Monographs, 14. 115-131.

Barba, E.; A., R.G. and Sánchez, A.J. 2005. Distribution patterns of estuarine caridean shrimps in the southwestern Gulf of Mexico. Crustaceana, 78: 708726.

Barba, E.; Juárez Flores, J. and Estrada Loreto, F. 2010. Distribución y abundancia de crustáceos en humedales de Tabasco, México. Revista Mexicana de Biodiversidad, 81: 153-164.

Bullis Jr, H.R. and Thompson, J.R. 1965. Collections by the exploratory fishing vessels Oregon, Silver Bay, Combat, and Pelican made during 1956-1960 in the southwestern North Atlantic. U.S. Fish and Wildlife Service, Special Scientific Report-Fisheries, 510: 1-130.

Chace, F.A., Jr. 1970. A new shrimp of the genus Lysmata (Decapoda, Hippolytidae) from the western Atlantic. Crustaceana, 19: 59-66.

Chace, F.A.J. 1972. The shrimps of the SmithsonianBredin Caribbean expeditions with a summary of West Indian shallow-water species (Crustacea: Decapoda: Natantia). Smithsonian Contributions to Zoology, 98: 1-179.

Christoffersen, M.L. 1987. Phylogenetic relationships of hippolytid genera, with an assignment of new families for the Crangonoidea and Alpheoidea (Crustacea, Decapoda, Caridea). Cladistics, 3: 348362.

d'Udekem d'Acoz, C. 2000. First record of Janicea antiguensis (Chace, 11972) from the Cape Verde Islands and in the eastern Atlantic (Decapoda, Caridea, Hippolytidae). Crustaceana, 73: 11631166.

Dana, J.D. 1852. Conspectus Crustaceorum \&c. Conspectus of the Crustacea of the Exploring Expedition under Capt. C. Wilkes, U.S.N. Macroura. Proceedings of the Academy of Natural Sciences of Philadelphia, 2: 10-29.

Dardeau, M.R.; Adkinson, D.L.; Shaw, J.K. and Hopkins, T.S. 1980. Notes on the distribution of four caridean shrimps (Crustacea: Decapoda) in the northeastern Gulf of Mexico. Florida Scientist, 43: 54-57.

De Grave, S. 2009. A further sponge-dwelling species of the Periclimenes iridescens complex from the western Atlantic (Decapoda, Caridea, Palaemonidae). Crustaceana, 82: 829-836.

De Grave, S. and Felder, D.L. 2012. The genus Processa in the vicinity of Carrie Bow Cay (Belize) with description of a new species (Crustacea: Decapoda: Processidae) Zootaxa, 3436: 41-50.

De Grave, S. and Fransen, C.H.J.M. 2011. Carideorum catalogus: the recent species of the dendrobranchiate, stenopodidean, procarididean and caridean shrimps (Crustacea: Decapoda). Zoologische Mededelingen, 85: 195-589.

Duchassaing De Fonbressin, P. and Michelotti, G. 1864. Spongiaires de la mer Caraïbe. Natuurkundige verhandelingen van de Hollandsche maatschappij der wetenschappen te Haarlem, 21: 1-124.

Escobar-Briones, E. and Jiménez-Guadarrama, E.L. 2010. Macrocrustáceos (Peracarida, Decapoda) de fondos carbonatados del sector occidental del Banco de Campeche en el sur del Golfo de México. Revista Mexicana de Biodiversidad, 81: 63-72.

Escobar-Briones, E. and Villalobos-Hiriart, J.L. 2003. Deep-water caridean shrimps (Crustacea: Decapoda) from Banco Chinchorro and adjacent areas in the 
northern Caribbean. Bulletin of Marine Science, 73: 99-122.

Felder, D.L.; Álvarez, F.; Goy, J.W. and Lemaitre, R. 2009. Decapoda (Crustacea) of the Gulf of Mexico, with comments on the Amphionidacea. In: Felder, D.L. and Camp, D.K. (Eds.), Gulf of Mexico Origin, Waters, and Biota Volume 1, Biodiversity. Texas A\&M University Press, College Station, Texas: pp. 1019-1104.

Fransen, C.H.J.M. 2002. Taxonomy, phylogeny, historical biogeography, and historical ecology of the genus Pontonia Latreille (Crustacea: Decapoda: Caridea: Palaemonidae). Zoologische Verhandelingen, 336: 1-433.

Fransen, C.H.J.M. 2006. On Pontoniinae (Crustacea, Decapoda, Palaemonidae) collected from ascidians. Zoosystema, 28: 713-746.

García-Madrigal, M.S.; Campos-Vázquez, C. and González, N.E. 2002. Sección de Crustáceos de la Colección de referencia de bentos costero de ECOSUR - Crustaceans section of the reference colection of coastal benthos from ECOSUR. Universidad y Ciencia - Universidad Juárez Autónoma de Tabasco, 36: 140-148.

Gibbes, L.R. 1850. On the Carcinological Collections of the United States, and an enumeration of species contained in them, with notes on the most remarkable, and descriptions of new species. Proceedings of the American Association for the Advancement of Science, third meeting: 167-201.

Giraldes, B.W.; Coelho Filho, P.A.; Coelho, P.A. and Anker, A. 2012. Confirmation of the presence of Janicea antiguensis (Chace, 1972) (Decapoda: Barbouriidae) in northeastern and eastern Brazil. Nauplius, 20: 171-178.

Goy, J.W. 2005. Stenopodid shrimps. In: HernándezAguilera, J.L.; Ruiz-Nuño, J.A.; Toral-Almazán, R.E. and Arenas-Fuentes, V. (Eds.), Camarones, Langostas y Cangrejos de la Costa Este de México. Econatura-CONABIO, México DF: pp. 203-206.

Gracia, A. and Hernández-Aguilera, J.L. 2005. Camarones Penaeoideos. In: Hernández-Aguilera, J.L.; Ruiz-Nuño, J.A.; Toral-Almazán, R.E. and Arenas-Fuentes, V. (Eds.), Camarones, Langostas y Cangrejos de la Costa Este de México. EconaturaCONABIO, México DF: pp. 23-66.

Hale, R. and De Grave, S. 2007. The first record of Periclimenes platalea Holthuis, 1951 (Decapoda, Pontoniinae) in the western Atlantic. Crustaceana, 80: 1019-1021.

Hay, W.P. 1917. Preliminary descriptions of five new species of crustaceans from the coast of North Carolina. Proceedings of the Biological Society of Washington, 30: 71-74.

Hay, W.P. and Shore, C.A. 1918. The decapod crustaceans of Beaufort, N. C., and the surrounding region. Bulletin of the United States Burean of Fisheries, 35: 369-475.

Heard, R.W. 1986. Pontoniine shrimps (Decapoda: Caridea: Palaemonidae) of the Northwest Atlantic. I. The genus Neopontonides Holthuis, 1951, with the description of $N$. chacei, new species, and the erection of Pseudopontonides, new genus, to receive $N$. principes Criales, 1980. Journal of Crustacean Biology, 6: 471-484.

Hermoso-Salazar, A.M. and Arvizu-Coyotzi, K. 2007. Los estomatópodos y decápodos del Parque Nacional Sistema Arrecifal Veracruzano. In: Granados-Barba, A.; Abarca-Arenas, L. and Vargas-Hernández, J.M.
(Eds.), Investigaciones Cientificas en el Sistema Arrecifal Veracruzano. Universidad Autónoma de Campeche: pp. 101-112.

Hernández-Aguilera, J.L.; Gracia, A. and Illescas, C. 2010. Macrocrustáceos acuáticos. In: Villalobos-Zapata, G. and Mendoza, J. (Eds.), La Biodiversidad en Campeche - Estudio de Estado. Comisión Nacional para el Conocimiento y Uso de la Biodiversidad (CONABIO), Gobierno del Estado de Campeche, Universidad Autónoma de Campeche (UAC), El Colegio de la Frontera Sur (ECOSUR), Mexico: pp. 270-274.

Hernández-Aguilera, J.L.; Toral-Almazán, R.E. and Ruiz-Nuño, J.A. 1996. Especies catalogadas de crustáceos estomatópodos y decápodos para el Golfo de México, Rio Bravo, Tampico a Progreso, Yucatán. Conabio, Dirección de Oceanografia, Secretaría de Marina, México.

Hernández, C.; Álvarez, F. and Villalobos, J.L. 2010. Crustáceos Asociados a sustrato duro en la zona intermareal de Montepío, Veracruz, México. Revista Mexicana de Biodiversidad, 81: 141-152.

Holthuis, L.B. 1951a. The caridean Crustacea of tropical West Africa. Atlantide Report, 2: 1-187.

Holthuis, L.B. 1951b. A general revision of the Palaemonidae (Crustacea Decapoda Natantia) of the Americas. I. The subfamilies Euryrhynchinae and Pontoniinae. Allan Hancock Foundation Publications, Occasional Papers, 11: 1-332.

Kensley, B. 1988. New species and records of cave shrimps from the Yucatan peninsula (Decapoda: Agostocarididae and Hippolytidae). Journal of Crustacean Biology, 8: 688-699.

Linnaeus, C. 1758. Systema Naturae per regna tria naturae, secundum classes, ordines, genera, species, cum characteribus, differentiis, synonymis, locis. Laurentius Salvius: Holmiae. ii.

Manning, R.B. 1963. The east American species of Gnathophyllum (Decapoda: Caridea), with the description of a new species. Crustaceana, 5: 47-63.

Manning, R.B. and Hart, C.W., Jr. 1984. The status of the hippolytid shrimp general Barbouria and Ligur (Crustacea: Decapoda): a reevaluation. Proceedings of the Biological Society of Washington, 97: 655-665.

Marin, I. 2009. A review of the pontoniine shrimp genus Rapipontonia Marin, 2007 (Decapoda: Caridea: Palaemonidae), with the description of a new species from the Indo-West Pacific. Zootaxa, 2289: 1-17.

Markham, J.C.; Donath-Hernandez, F.E.; VillalobosHiriart, J.L. and Diaz-Barriga, A.C. 1990. Notes on the shallow-water marine Crustacea of the Caribbean coast of Quintana Roo, Mexico. Anales del Instituto de Biología, Universidad Nacional Autonoma de Mexico, Serie Zoología, 61: 405-446.

Martínez-Guzmán, L.A. and Hernández-Aguilera, J.L. 1993. Crustáceos Estomatópodos y Decápodos del Arrecife Alacrán, Yucatán. In: Salazar-Vallejo, S.I. and Gonzalez, N.E. (Eds.), Biodiversidad Marina y Costera de México. CONABIO and CIQRO, México: pp. 609-629.

Martínez-Mayén, M. and Román-Contreras, R. 2006. A new species of Periclimenes Costa, 1844 (Crustacea: Decapoda: Palaemonidae) from the Caribbean 
coast of Quintana Roo, Mexico, and a key to the "iridescens" complex. Proceedings of the Biological Society of Washington, 119: 32-42.

McClendon, J.F. 1911. On adaptations in structure and habits of some marine animals of tortugas, Florida. Papers from the Marine Biological Laboratory at Tortugas: 53-64.

McClure, M.R. 2005. Snapping Shrimps. In: Hernández-Aguilera, J.L.; Ruiz-Nuño, J.A.; ToralAlmazán, R.E. and Arenas-Fuentes, V. (Eds.), Camarones, Langostas y Cangrejos de la Costa Este de México. Econatura-CONABIO, México, DF: pp. 119-202.

Mejía-Ortiz, L.M. (Ed) 2008. Biodiversidad acuatica de la Isla de Cozumel. Universidad de Quintana Roo, México, D.F.

Ortmann, A.E. 1890. Die Unterordnung Natantia Boas: Die Decapoden-Krebse des Strassburger Museums, mit besonderer Berücksichtung der von Herrn Dr. Döderlein bei Japan und bei den Liu-Kiu-Inseln gesammelten und z. Z. im Strassburger Museum aufbewahrten Formen. I. Zoologische Jahrbücher. Abteilung für Systematik, Geographie und Biologie der Thiere, 5: 437-542.

Pachelle, P.P.G.; Paiva, S.V.; Oliveira, R.R. and Anker, A. 2012. The ascidian-associated shrimp Ascidonia miserabilis (Caridea: Palaemonidae): first record for Brazil and additional records for the Caribbean Sea. Marine Biodiversity Records, 5: e83.

Pallas, P.S. 1766. Elenchus zoophytorum. Van Cleef, Hagae-Comitum.

Rafinesque, C.S. 1815. Analyse de la Nature, ou Tableau de l'Univers et des Corps Organisés. L'Imprimerie de Jean Barravecchia, Palermo.

Ramos-Porto, M. and Coelho, P.A. 1990. Sinopse dos crustáceos decápodos brasileiros (família Palaemonidae). Anais da Sociedade Nordestina de Zoologia, 3: 93-111.

Ramos-Porto, M. and Coelho, P.A. 1991. Sinopse dos crusáceos decápodos Brasileiros (Família Hippolytidae). Trabalhos Oceanográficos da Universidade Federal de Pernambuco, 22: 181.

Rathbun, M.J. 1901. The Brachyura and Macrura of Porto Rico. Bulletin of the United States Fish Commission, 20 [for 1900]: 1-127.

Raz-Guzmán, A. 2010. Estudio de caso: crustáceos de la laguna de Términos. In: Villalobos-Zapata, G. and Mendoza, J. (Eds.), La Biodiversidad en Campeche - Estudio de Estado. Comisión Nacional para el Conocimiento y Uso de la Biodiversidad (CONABIO), Gobierno del Estado de Campeche, Universidad Autónoma de Campeche (UAC), El Colegio de la Frontera Sur (ECOSUR), Mexico: pp. 275-279.

Rhyne, A.L. and Anker, A. 2007. Lysmata rafa, a new species of peppermint shrimp (Crustacea, Caridea, Hippolytidae) from the subtropical western Atlantic. Helgoland Marine Research, 61: 291-296.

Rhyne, A.L.; Calado, R. and Dos Santos, A. 2012. Lysmata jundalini, a new peppermint shrimp (Decapoda, Caridea, Hippolytidae) from the Western Atlantic. Zootaxa, 3579: 71-79.

Rhyne, A.L. and Lin, J. 2006. A western Atlantic peppermint shrimp complex: Redescription of Lysmata wurdemanni, description of four new species, and remarks on Lysmata rathbunae (Crustacea: Decapoda: Hippolytidae). Bulletin of Marine Science, 79: 165-204.

Rodríguez-Almaraz, G.A.; Leija-Triztán, A. and Mendoza, R. 2000. Records of Caridean shrimps
(Crustacea: Decapoda) from the coasts of the Mexican Pacific Ocean, Gulf of Mexico and Mexican Caribbean. Bulletin of Marine Science of the Gulf and Caribbean, 67: 857-867.

Román-Contreras, R. 1988. Características ecológicas de los crustáceos decápodos de la Laguna de Terminos, Mexico. In: Yañez-Arancibia, A. and Day Jr., J.W. (Eds.), Ecología de los sistemas costeros en el sur del Golfo de México: La región de la Laguna de Términos. Organización de Estados Americanos Universidad Nacional Autónoma de México, México, D.F.: pp. 305-323.

Román-Contreras, R. and Martínez-Mayén, M. 2007. First record of Nikoides schmitti Manning \& Chace, 1971 (Decapoda, Caridea, Processidae) in Mexican waters. Crustaceana, 80: 125-127.

Román-Contreras, R. and Martínez-Mayén, M. 2009. Camarones hipolítidos (Crustacea: Decapoda: Caridea) de aguas someras de la costa del Caribe mexicano. Hidrobiologica, 19: 119-128.

Román-Contreras, R. and Martínez-Mayén, M. 2010a. Notes on marine shallow-water carideans (Pasiphaeidae, Gnathopyllidae, and Processidae) from Quintana Roo, Mexico. Crustaceana, 83: 957970.

Román-Contreras, R. and Martínez-Mayén, M. 2010b. Notes on some alpheid shrimps (Decapoda: Caridea) of Thalassia testudinum meadows, from the CentralSouthern Mexican Caribbean. Hidrobiologica, 20: 222-229.

Román-Contreras, R. and Martínez-Mayén, M. 2010c. Palaemonidae (Crustacea: Decapoda: Caridea) from the shallow waters from Quintana Roo, Mexican Caribbean coast. Revista Mexicana de Biodiversidad, 81: 43-51.

Román-Contreras, R. and Romero-Rodríguez, J. 2005. Incidence of infestation of Bopyrina abbreviata Richardson, 1904 (Isopoda: Bopyridae) on Hippolyte zostericola (Smith, 1873) (Decapoda: Hippolytidae) in Laguna de Términos, Gulf of Mexico. Nauplius, 13: 83-88.

Schmitt, W.L. 1932. Appendix in Pearse, Inhabitants of certain sponges at Dry Tortugas. Carnegie Institute of Washington Publication [also published as Papers of the Tortugas Laboratory, vol. 28], 435: 123-124.

Schmitt, W.L. 1936. Zoologische Ergebnisse einer Reise nach Bonaire, Curaçao und Aruba im Jahre 1930. No. 16. Macruran and anomuran Crustacea from Bonaire, Curaçao and Aruba. Zoologische Jahrbücher. Abteilung für Systematik, Ökologie und Geographie der Tiere, 67: 363-378.

Soto, L.A. 1980. Decapod Crustacea shelf-fauna of the northeastern Gulf of Mexico. Anales Centro de Ciencias del Mar y Limnologia: 79-110.

Spence Bate, C. 1888. Report on the Crustacea Macrura collected by H.M.S. Challenger during the Years 1873-76. In: Murray, J. (Ed.), Zoology. Neill and Company, Edinburgh: pp. i-xc, 1-942.

Vieira, R.R.R.; Ferreira, R.S. and D'Incao, F. 2012. Pontoniinae (Crustacea: Decapoda: Caridea) from Brazil with taxonomic key. Zootaxa, 3149: 1-38.

Wicksten, M.K. 1983. A monograph on the shallow water caridean shrimps of the Gulf of California, Mexico. Allan Hancock Monographs in Marine Biology, 13: 1-59.

Wicksten, M.K. 2005a. Decapod crustaceans of the Flower Garden Banks National Marine Sanctuary. Gulf of Mexico Science, 23: 30-37.

Wicksten, M.K. 2005b. Hippolytid shrimps. In: Hernández-Aguilera, J.L.; Ruiz-Nuño, J.A.; Toral- 
Almazán, R.E. and Arenas-Fuentes, V. (Eds.), Camarones, Langostas y Cangrejos de la Costa Este de México. Econatura-CONABIO,, México, DF: pp. 98-118.

Wicksten, M.K. 2005c. Palaemonid shrimps. In: Hernández-Aguilera, J.L.; Ruiz-Nuño, J.A.; ToralAlmazán, R.E. and Arenas-Fuentes, V. (Eds.), Camarones, Langostas y Cangrejos de la Costa Este de México. Econatura-CONABIO, México DF: pp. 67-97.

Wicksten, M.K. and Cox, C. 2011. Invertebrates associated with gorgonians in the northern Gulf of Mexico. Marine Biodiversity Records, 4: e79.

Williams, A.B. 1965. Marine decapod crustaceans of the Carolinas. Fishery Bulletin of the Fish and Wildlife Service, 65: 1-298.

Wirtz, P. 2004. Four amphi-Atlantic shrimps new for Sáo Tomé and Príncipe. Arquipélago, Life and Marine Science, 21A: 83-85.

Wirtz, P. and d'Udekem d'Acoz, C. 2001. Decapoda from Antipatharia, Gorgonaria and Bivalvia at the Cape Verde Islands. Helgoländer Meeresuntersuchungen, 55: 112-115.

Wirtz, P. and De Grave, S. 2010. Shrimps (Crustacea, Decapoda, Caridea) associated with gorgonian at the coast of Senegal. Arquipélago, 27: 69-71.

Wirtz, P.; Melo, G.A.S. and De Grave, S. 2009. Symbioses of decapod crustaceans along the coast of Espírito Santo, Brazil. Marine Biodiversity Records, 2: e162.

Zarco-Perelló, S.; Mascaro-Miquelajauregui, M.; GarzaPérez, R. and Simóes, N. 2013. Minor Reefs of the Campeche Bank, Yucatán, México: Topography and Coral Community. Hidrobiologica, 23: 28-41.

Zea, S. and van Soest, R.W.M. 1986. Three new species of sponges from the Colombian Caribbean. Bulletin of Marine Science, 38: 355-365. 